\title{
Microbial plankton assemblages, composition and biomass, during two ice-free periods in a deep high mountain lake (Estany Redó, Pyrenees)
}

\author{
Marisol FELIP*, Frederic BARTUMEUS ${ }^{1)}$, Silvana HALAC ${ }^{1)}$ and Jordi CATALAN ${ }^{1)}$ \\ Institute of Zoology and Limnology, Innsbruck University, Technikerstr. 25, A-6020 Innsbruck, Austria \\ ${ }^{1)}$ Departament d'Ecologia i Centre de Recerca d'Alta Muntanya, Universitat de Barcelona, Av. Diagonal 645, 08028 Barcelona, Spain \\ *e-mail corresponding author: Marisol.Felip@uibk.ac.at; marisol@porthos.bio.ub.es
}

\begin{abstract}
Microbial plankton composition and biomass were monitored for two ice-free periods in a deep oligotrophic high-mountain lake (Redó, Pyrenees). Phytoplankton dominated microbial biomass, while the relationship between total water-column-integrated autotrophic and heterotrophic biomass ranged from 1.5 to 6.5 (an average of 4.4). Heterotrophic biomass was dominated by bacteria (an average of $47 \%$ ), but heterotrophic nanoflagellates and, to a lesser degree, ciliates occasionally constituted a sizeable proportion. In general, the microbial biomass ratios were 10:2:2:1 for PHY:BAC:HNF:CIL. About one hundred eukaryotic species were found, although most of them in low abundance and frequency. Phytoplankton biomass was dominated by flagellated chrysophytes and dinoflagellates (an average of 40 and 32\% respectively); occasionally cryptophytes (in deep layers) and chlorococcal chlorophytes (during the autumn mixing period) were also significant. In the two years sampled, the maximum phytoplankton diversity was observed during the autumn mixing period. Heterotrophic flagellate biomass was dominated by chrysophytes (78\% on average), but sporadically a non-identified species reached high abundances. Oligotrichs, (an average of $43 \%$ of total ciliate biomass) dominated the ciliate community, still other groups (gymnostomatida and prostomatida) were also significant. Bacteria biomass was largely homogeneous throughout the two periods, but size segregation was observed especially when the lake was stratified, with larger bacteria appearing in the upper layers. The highest planktonic microbial biomass occurred during the mixing periods, mainly during spring. But no clear relationships were found between the temporal distribution of bacteria, phytoplankton, heterotrophic flagellate and ciliate biomass.
\end{abstract}

Key words: phytoplankton, bacteria, heterotrophic flagellate, ciliate, oligotrophic lakes

\section{INTRODUCTION}

High mountain lakes are particularly suitable systems in which to study a number of plankton processes. Extreme conditions of light, UV radiation, temperature, low nutrients and the presence of an ice cover during several months each year are key factors in understanding their plankton dynamics (Pechlaner 1971). The importance of microbial assemblages in the transfer of energy and matter in pelagic environments has been demonstrated for marine (Azam et al. 1983) and freshwater ecosystems (Stockner \& Porter 1988). Furthermore, in oligotrophic systems, where production is mainly based on an internal recycling of nutrients, this importance would appear to be greater than in eutrophic environments (Porter et al. 1988, Weisse 1991). These general findings suggest that the microbial component plays an important role in the food webs of high mountain lakes. The microbial components of plankton consist of autotrophic and heterotrophic, pro- and eukaryotic unicellular organisms: bacteria, phytoplankton, heterotrophic flagellates and ciliates.

Studies of plankton in high mountain lakes were undertaken in the 70s, in the Tyrolian Alps (Pechlaner et al. 1970; Tilzer 1973) and in the Pyrenees (Capblanq 1972, Margalef et al. 1975). Later, studies carried out in
Lake Redó (Central Pyrenees) provided data on the relationships between physical, chemical, and biological features during a whole seasonal period (Catalan 1988, 1992; Felip 1997; Felip \& Catalan 1999). Most recent studies focus on more specific questions regarding high mountain lake plankton, such as the UV radiation effect (Halac et al. 1997; Sommaruga \& Garcia-Pichel 1999; Sommaruga et al. 1999) or the microbial community inhabiting the ice and snow cover (Felip et al. 1995, 1999). However, studies related to the community structure and composition of all the microbial components, and their seasonal changes, do not, to our knowledge, exist for these systems.

In this paper, we present a study of the composition of microbial assemblages (bacteria, phytoplankton, heterotrophic flagellates and ciliates) during two ice-free periods in a deep high mountain lake (Redó, Pyrenees), and we discuss the relative importance of the different stocks and the relationship between the autotrophic and heterotrophic fractions.

\section{METHODS}

The study was conducted in Lake Redó $\left(42^{\circ} 3^{\prime} \mathrm{N}\right.$, $\left.0^{\circ} 46^{\prime} \mathrm{E}\right)$, an oligotrophic high mountain lake in the Central Pyrenees (Spain) at $2240 \mathrm{~m}$ a. s. 1. It has a surface area of 24 ha, a maximum depth of $73 \mathrm{~m}$ and a 
mean depth of $32 \mathrm{~m}$. A complete description of its physical and chemical features can be found in Catalan (1988, 1989, 1992). It is a dimictic lake, which is usually covered by ice and snow for 6-7 months a year.

The lake was sampled at the maximum depth point every month during the ice-free period of 1996 (from July to December) and 1997 (from June to December). Water samples were obtained at $9 \mathrm{~m}$ depth intervals from 0 to $63 \mathrm{~m}$. Immediately after sampling, subsamples were fixed for the subsequent determination of microbial abundance and composition. Samples for autotrophic picoplankton (PICO) were preserved with formaldehyde and rapidly quantified by epifluorescence microscopy (MacIsaac \& Stockner 1993). Samples for bacteria (BAC) and heterotrophic nanoflagellate (HNF) enumeration were also preserved with formaldehyde and processed by epifluorescence microscopy, using DAPI staining on black Nucleopore filters (pore size 0.2 $\mu \mathrm{m}$ and $0.8 \mu \mathrm{m}$ ) following the techniques described in Porter \& Feig (1980) and Sherr \& Sherr (1993). Abundances of phytoplankton (PHY) and ciliates (CIL) were estimated using the Utermöhl method after fixation with Lugol's solution (Sournia 1978). Bacterial biomass, size, and shape were determined by automated image analysis as described in Felip et al. (1995). The volume of all other microorganisms was estimated by shape assimilation to known geometric forms and by measuring the main cell dimensions. If size differences were observed within a species of phytoplankton or ciliates, the individuals of that species were divided into several cell size classes in order to evaluate their volume more accurately. Carbon conversion was assessed according to lit-

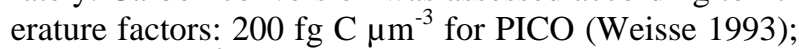

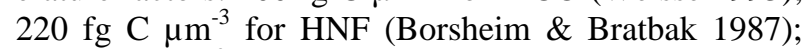

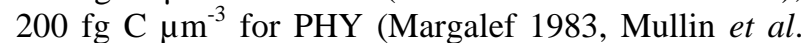

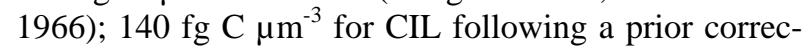
tion of cell volumes by a factor of 1.4 (Putt \& Stoecker 1989, Müller \& Geller 1993); and for BAC, we used the allometric equation proposed by Norland (1993). A more detailed description of the procedures can be found in Wathne \& Hansen (1997) and in Straškrabová et al. (1999, this volume).

\section{RESULTS}

\subsection{Microbial assemblage diversity}

During both ice-free periods the bacterial population was dominated by short rods and cocci between 0.4-0.6 $\mu \mathrm{m}$ long, while cells up to $1.32 \mu \mathrm{m}$ were observed (Tab. 1). Although cell size variability was relatively low, it did change with depth so that larger bacteria were found in the upper layers (Fig. 1), especially when the lake water column was stratified (September 96, August and September 97).

Autotrophic picoplankton were almost absent from Lake Redó and usually no cells were observed during the epifluorescence microscopy exploration. During phytoplankton counts, two species of picocyanobacteria were observed sporadically, although they never occurred in high abundances (Tab. 2).

Tab. 1. Average and range of sample bacterial abundance, biovolume and biomass, and average cell measures (length, width, volume and $\mathrm{C}$ content) determined by image analysis.

\begin{tabular}{lccc}
\hline & Average & Maximum & Minimum \\
\hline Cell length $(\mu \mathrm{m})$ & 0.64 & 1.32 & 0.4 \\
Cell width $(\mu \mathrm{m})$ & 0.27 & 0.32 & 0.23 \\
Cell volume $\left(\mu \mathrm{m}^{3}\right)$ & 0.03 & 0.06 & 0.01 \\
Cell C-content $(\mathrm{fg})$ & 9.15 & 13.15 & 5.54 \\
Abundance $\left(\mathrm{cells} \mathrm{ml}^{-1}\right)$ & 415291 & 1274937 & 176661 \\
Biovolume $\left(\mu \mathrm{m} \mathrm{m}^{-1}\right)$ & 14264 & 28639 & 5831 \\
Biomass $\left(\mu \mathrm{g} \mathrm{C} \mathrm{m}^{-1}\right)$ & 3.93 & 9.2 & 1.83 \\
\hline
\end{tabular}

About one hundred eukaryotic species were counted, although the abundance and frequency of most was low. Table 2 lists the main species, including the heterotrophic flagellates which we were able to determine during phytoplankton counts. Xanthophyceae, bacillariophyceae, prymnesiophyta and desmidiales were poorly represented in Lake Redó's phytoplankton, be it in number of species, abundance or frequency (Tab. 2). All these groups accounted, on average, for less than $0.5 \%$ of the total phytoplankton biovolume (Tab. 3). Chlorophyta and chrysophyceae were the main phytoplankton groups in terms of species number and abundance, with Dictyosphaerium cf. subsolitarium, Sphaerocystis schroeteri, Chromulina spp. Ochromonas sp.2, Pseudokephyrion inflatum and Stichogloea doederleinii being the most abundant species. In contrast, in terms of percentage biovolume the main groups were chrysophyceae and dinophyta, whereas chryptophyta and chlorococcales were only occasionally of any significance (Tab. 3). Figure 2 shows the changes in the percentage of phytoplankton biovolume for the main algae groups during 1996 and 1997 samplings. Temporal trends were similar in both years: chrysophyceae and dinophyta dominated during spring (June and July); chlorococcales increased throughout the summer (August and September) and phytoplankton appeared with greater diversity at the end of the autumn mixing (December). In contrast, cryptophyta were mostly associated with deep layers, where they became the dominant group (i.e., October 1996-97).

More than 20 species of heterotrophic flagellates were counted, though the diversity within the group is difficult to evaluate due to the complexities of taxonomic identification. Heterotrophic chrysophytes was the main group, accounting on average for more than $78 \%$ of the total heterotrophic flagellate biovolume, but the most abundant species could not be reliably identified (Tabs 2 and 3). Prostomatida were the most diverse ciliate group, and together with Oligotrichs and Gymnostomes they dominated ciliate assemblages in terms of species abundance, sample frequency and percentage 


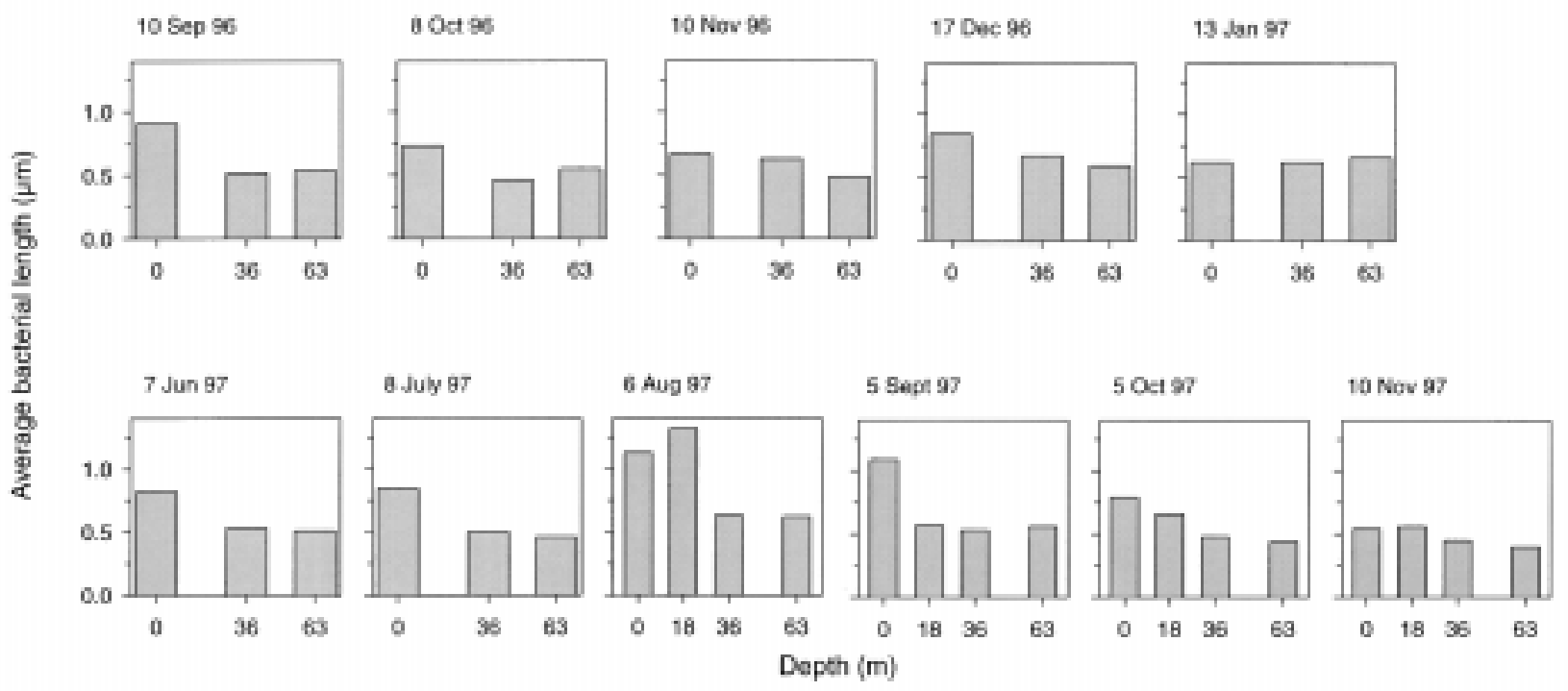

Fig. 1. Sample average of bacterial length determined by image analysis, ice-free periods of 1996 and 1997.

of total ciliate biovolume (Tabs 2 and 3). Some ciliate species (Askenasia spp., Urotricha pelagica, Rimostrombidium sp. and Strombidium sp.) were found in a large number of samples (Tab. 2).

\subsection{Changes in microbial biomass}

Bacterial abundance and biomass were usually low and did not change significantly throughout the period studied. The highest value of bacterial biomass was recorded in October 1996 at a depth of $36 \mathrm{~m}$, whereas the lowest value was recorded at the bottom of the lake in July 1997 (Tab. 1).

During 1996 and 1997 the distribution of phytoplanton biovolume differed slightly (Fig. 3). In both years, values peaked in spring (June and July) before decreasing throughout the summer. However, the increase observed during the 1996 autumn mixing period (November) was not recorded in 1997. The highest values were always found between depths of 18 and $27 \mathrm{~m}$. The maximum biovolume $\left(1177 \mathrm{~mm}^{3} \mathrm{~m}^{-3}\right)$ was reached in June 1997, whereas in July 1997 values were similar to those measured in July $1996\left(490 \mathrm{~mm}^{3} \mathrm{~m}^{-3}\right)$.

Heterotrophic flagellate biovolume was greatest at the beginning of the summer stratification, in the upper layers in $1996\left(130 \mathrm{~mm}^{3} \mathrm{~m}^{-3}\right)$ and at a depth of around $36 \mathrm{~m}$ in $1997\left(76 \mathrm{~mm}^{3} \mathrm{~m}^{-3}\right)$. Later, the maximum volume shifted to deeper layers and decreased during the rest of the period, especially in 1997 (Fig. 4).

Ciliate biovolume was also greatest during spring, reaching values of $80 \mathrm{~mm}^{3} \mathrm{~m}^{-3}$ in 1996 and up to 104 $\mathrm{mm}^{3} \mathrm{~m}^{-3}$ in 1997 , at a depth of $27 \mathrm{~m}$. During the rest of the period, the biovolume decreased, but showed a slight increase in September 1996 when values close to $76 \mathrm{~mm}^{3} \mathrm{~m}^{-3}$ were measured at depth of $36 \mathrm{~m}$ (Fig. 5).
In order to compare the temporal changes in the microbial plankton biomass, column integrated values were calculated for each group, taking into account lake volume and area. Apart from the initial increase in phytoplankton and ciliate biomass observed in June 1997, all microbial groups showed higher biomass and more marked temporal changes during 1996 (Fig. 6). Indeed, in 1996 phytoplankton reached similar values in July and November. The increase in heterotrophic flagellate biomass in autumn was more apparent than in the vertical distribution (Fig. 4), coinciding with a decrease in bacterial biomass (Fig. 6). On the other hand, opposite trends between heterotrophic flagellate and ciliate biomass changes were observed when both groups reached high values (July-September 1996, June-September 1997).

\subsection{Autotrophic versus heterotrophic biomass}

The biomass ranges for the microbial components of plankton measured in Lake Redó are summarized in table 4. Proportions and ratios were calculated for samples with data for all the groups available (35 samples). Algae dominated microbial biomass, with maximum and minimum phytoplankton percentages being observed in July 1997 at depths of 0 and $63 \mathrm{~m}$ respectively. Considering the values calculated for the whole lake (total water-column-integrated biomasses): phytoplankton ranged between $61-87 \%$ (average $80 \%$ ); and the ratio between autotrophic and heterotrophic biomass ranged between 1.5-6.5 (average 4.4). Heterotrophic biomass was dominated by bacteria, which represented on average almost half of the heterotrophic biomass, but the range of variation was high for the three groups of heterotrophs (Tab. 4). 
Tab. 2. List of the main microbial species identified in Lake Redó plankton. Freq = frequency in samples (\%), and Max Ab. $=$ maximum abundance $\left(\right.$ ind $\mathrm{ml}^{-1}$ ), measured during 1996 and 1997 ice-free periods.

\begin{tabular}{|c|c|c|c|c|c|}
\hline \multirow{2}{*}{ PHYTOPLANKTON } & & \multicolumn{2}{|c|}{1996} & \multicolumn{2}{|c|}{1997} \\
\hline & & Freq. & Max Ab. & Freq. & Max Ab. \\
\hline \multirow[t]{2}{*}{ CYANOBACTERIA } & Chroococcus sp.1 & 21 & 16 & 2 & 2 \\
\hline & Synechocystis sp. & & & 11 & 9 \\
\hline \multicolumn{6}{|l|}{ CHLOROPHYTA } \\
\hline \multirow[t]{12}{*}{ Volvocales } & Chlamydomonas sp.1 & 52 & 6 & 36 & 12 \\
\hline & Chlamydomonas sp.2 & 13 & 0,6 & 7 & 3 \\
\hline & Chlamydomonas sp. 3 & & & 4 & 0,6 \\
\hline & Chlamydomonas sp.4 & 21 & 3,4 & 23 & 2 \\
\hline & Chlamydomonas nivalis & 17 & 0,04 & 4 & 2 \\
\hline & Chloromonas groveii & 29 & 4 & 41 & 16 \\
\hline & Chloromonas modesta & 13 & 3 & & \\
\hline & Chloromonas sp. 1 & 33 & 5 & 38 & 33 \\
\hline & Dysmorphococcus variabilis & 4 & 0,5 & 2 & 0,6 \\
\hline & Provasoliella sp. & & & 5 & 2 \\
\hline & Pteromonas sp. & & & 5 & 2 \\
\hline & Tetrablepharis globulosus & 8 & 0,9 & 2 & 1 \\
\hline \multirow[t]{10}{*}{ Chlorococcales } & Ankistrodesmus fusiformis & 90 & 35 & 63 & 19 \\
\hline & Botryococcus braunii & 4 & 0,14 & 27 & 0,66 \\
\hline & Dictyosphaerium cf. subsolitarium & 98 & 1094 & 91 & 862 \\
\hline & Monoraphidium sp. & 77 & 35 & 89 & 48 \\
\hline & Oocystis borgeii & 81 & 0,6 & 88 & 4 \\
\hline & Oocystis parva & 81 & 28 & 100 & 26 \\
\hline & Pseudoquadrigula sp. & 21 & 3 & 48 & 28 \\
\hline & Pseudosphaerocystis sp. & & & 9 & 105 \\
\hline & Sphaerocystis schroeteri & 100 & 737 & 100 & 1349 \\
\hline & Trochiscia sp. & & & 5 & 0.1 \\
\hline Desmidiales & Cosmarium sp. & 8 & 0,78 & 43 & 10 \\
\hline \multirow[t]{2}{*}{ XANTHOPHYCEAE } & Itsmochloron trispinatum & 13 & 4 & 36 & 16 \\
\hline & Monallantus sp. & & & 29 & 37 \\
\hline \multirow[t]{18}{*}{ CHRYSOPHYCEAE } & Bitrichia sp. & 29 & 3 & 32 & 5 \\
\hline & Chromulina parvula & 81 & 33 & 96 & 444 \\
\hline & Chromulina spp. & 79 & 141 & 96 & 2300 \\
\hline & Chrysococcus cf. rufescens & 81 & 53 & 66 & 25 \\
\hline & Chrysococcus sp. 1 & 73 & 55 & 27 & 24 \\
\hline & Chrysococcus sp. 2 & & & 21 & 28 \\
\hline & Chrysolykos skujae & 38 & 2 & 34 & 85 \\
\hline & Dinobryon cylindricum & 77 & 94 & 57 & 95 \\
\hline & Kephyrion planctonicum & & & 5 & 0,8 \\
\hline & Mallomonas sp. & 45 & 94 & 95 & 11 \\
\hline & Ochromonas globosa & & & 5 & 4 \\
\hline & Ochromonas sp.1 & & & 9 & 3 \\
\hline & Ochromonas sp. 2 & 98 & 1110 & 96 & 154 \\
\hline & Ochromonas sp. 3 & 96 & 65 & 84 & 47 \\
\hline & Ochromonas sp.5 & 29 & 1,4 & & \\
\hline & Pseudokephyrion inflatum & 94 & 180 & 93 & 1175 \\
\hline & Stichogloea doederleinii & 73 & 229 & 93 & 647 \\
\hline & Uroglena sp. & & & 13 & 0,2 \\
\hline \multirow[t]{4}{*}{ BACILLARIOPHYCEAE } & Aulacoseira $($ lirata + alpigena $)$ & 13 & 1 & 23 & 0.7 \\
\hline & Cyclotella pseudostelligera & & & 12 & 51 \\
\hline & Cyclotella sp. & & & 2 & 0.1 \\
\hline & Fragilaria nanana & 2 & 0,7 & 27 & 10 \\
\hline PRYMNESIOPHYTA & Chrysochromulina sp. & & & 14 & 3 \\
\hline \multirow[t]{4}{*}{ CRYPTOPHYTA } & Chroomonas acuta & 67 & 27 & 84 & 82 \\
\hline & Cryptomonas marsonii & 94 & 8 & 88 & 13 \\
\hline & Cryptomonas ovata & 100 & 28 & 93 & 11 \\
\hline & Rhodomonas minuta & 23 & 2 & 13 & 1 \\
\hline
\end{tabular}


Tab. 2. Continuation

\begin{tabular}{|c|c|c|c|c|c|}
\hline \multirow{2}{*}{ PHYTOPLANKTON } & & \multicolumn{2}{|c|}{1996} & \multicolumn{2}{|c|}{1997} \\
\hline & & Freq. & Max Ab. & Freq. & Max Ab. \\
\hline \multirow[t]{6}{*}{$\overline{\text { DINOPHYTA }}$} & Amphidinium elenkinii & 90 & 186 & 87 & 227 \\
\hline & Gymnodinium uberrimum & 79 & 2 & 91 & 6 \\
\hline & Gymnodinium cnecoides & 2 & 0,6 & 16 & 10 \\
\hline & Gymnodinium sp. 1 & 94 & 105 & 98 & 227 \\
\hline & Gymnodinium sp. 2 & 2 & 0,6 & 13 & 5 \\
\hline & Peridinium inconspicuum & 94 & 6 & 82 & 21 \\
\hline \multicolumn{6}{|c|}{ HETER. FLAGELLATES } \\
\hline \multirow[t]{5}{*}{ CHRYSOPHYCEAE } & Monas coronifera & 42 & 7 & 48 & 7 \\
\hline & Oikomonas termo & 75 & 0,3 & 73 & 12 \\
\hline & Spumella - Oikomonas spp. $3 \mu \mathrm{m}$ & 58 & 48 & 100 & 42 \\
\hline & Spumella - Oikomonas spp. $5 \mu \mathrm{m}$ & 79 & 21 & 100 & 51 \\
\hline & Spumella - Oikomonas spp. $10 \mu \mathrm{m}$ & 50 & 3 & 93 & 37 \\
\hline \multirow[t]{3}{*}{ CHOANOFLAGELLATES } & Monosiga ovata & 38 & 4 & 73 & 31 \\
\hline & Proterospongia sp. & 21 & 11 & & \\
\hline & Salpingoeca-like & & & 62 & 21 \\
\hline BODONIDS & Pleuromonas nasuta & 40 & 8 & 84 & 62 \\
\hline CRYPTOMONADS & Goniomonas truncata & & & 4 & 1 \\
\hline OTHERS & Tetramitus sp. & & & 2 & 5 \\
\hline \multirow[t]{9}{*}{ NON-IDENTIFIED FLAG. } & Non-identified species 1 & 73 & 39 & 84 & 61 \\
\hline & Non-identified species 2 & & & 13 & 6 \\
\hline & Non-identified species 4 & & & 4 & 0.02 \\
\hline & Non-identified species 5 & 81 & 88 & 95 & 288 \\
\hline & Non-identified species 6 & 17 & 2 & 86 & 43 \\
\hline & Non-identified species 7 & 50 & 5 & 29 & 12 \\
\hline & Non-identified species 8 & 15 & 2 & & \\
\hline & Non-identified species 9 & 19 & 0,9 & & \\
\hline & Non-identified species 11 & & & 11 & 6 \\
\hline \multicolumn{6}{|l|}{ CILIATES } \\
\hline COLPODEA & Non-identified species 1 & & & 9 & 0.05 \\
\hline \multirow[t]{6}{*}{ PROSTOMATIDA } & Balanion planctonicum & 31 & 5 & 38 & 14 \\
\hline & Holophrya sp. 1 & 2 & 0,06 & & \\
\hline & Urotricha furcata & 17 & 2,5 & 43 & 6 \\
\hline & Urotricha pelagica & 79 & 0,46 & 80 & 0,36 \\
\hline & Urotricha sp. 1 & 31 & 4 & 13 & 3 \\
\hline & Urotricha sp. 2 & & & 27 & 5 \\
\hline \multirow[t]{4}{*}{ GYMNOSTOMATIDA } & Askenasia spp. & 79 & 0,34 & 91 & 1,4 \\
\hline & Mesodinium pulex & 40 & 0,16 & 68 & 2 \\
\hline & Rhopalophrya sp. & 4 & 0,02 & 7 & 0,02 \\
\hline & Spathidium-like & 2 & 0,02 & 9 & 0,03 \\
\hline \multirow[t]{2}{*}{ HYMENOSTOMATA } & Stokesia vernalis & 2 & 0,04 & & \\
\hline & Uronema sp. & & & 5 & 0,18 \\
\hline \multirow[t]{3}{*}{ OLIGOTRICHIDA } & Pelagostrombidium fallax & 67 & 1,32 & 61 & 1,3 \\
\hline & Rimostrombidium sp. & 73 & 0,68 & 39 & 1,2 \\
\hline & Strombidium sp. & 73 & 2,2 & 61 & 4 \\
\hline SUCTORIA & Sphaerophrya sp. & & & 9 & 0,05 \\
\hline \multirow[t]{7}{*}{ NON-IDENT. CILIATES } & Non-identified species 1 & 6 & 0,12 & 2 & 0,01 \\
\hline & Non-identified species 2 & & & 2 & 0,01 \\
\hline & Non-identified species 3 & & & 2 & 0,01 \\
\hline & Non-identified species 5 & 6 & 0,06 & & \\
\hline & Non-identified species 6 & 4 & 0,08 & 2 & 0,01 \\
\hline & Non-identified species 7 & 2 & 0,02 & 2 & 0,02 \\
\hline & Non-identified species 8 & 4 & 0,04 & & \\
\hline
\end{tabular}




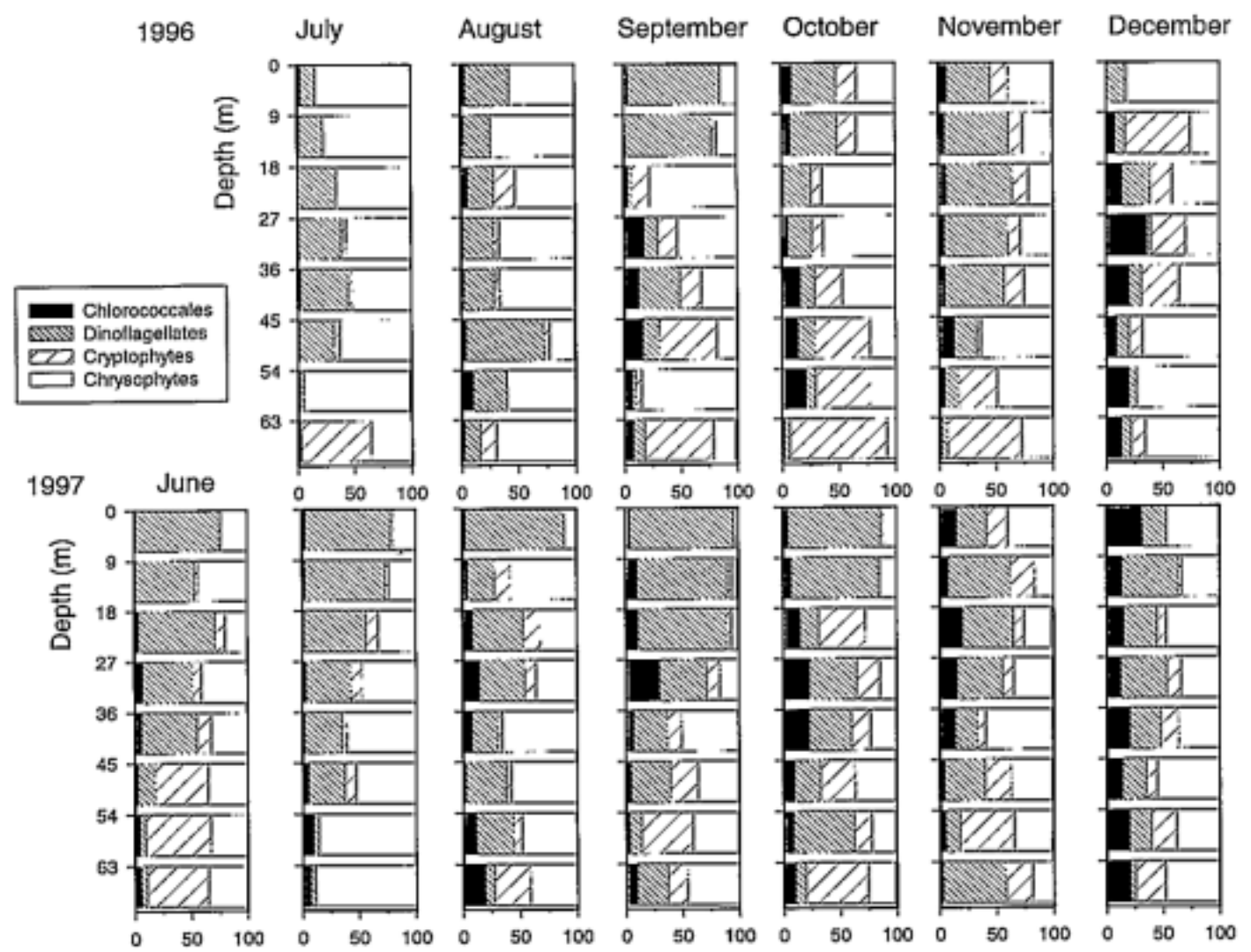

Fig. 2. Changes in phytoplankton composition throughout the studied period in biovolume percentage of the main taxonomic groups.

Tab. 3. Composition of planktonic microbial groups during 1996 and 1997 ice-free periods. Average and range of the biovolumes percentages for the different taxonomic categories encountered.

\begin{tabular}{lccc}
\hline & Average & Maximum & Minimum \\
\hline PHYTOPLANKTON & & & \\
Cyanobacteria & 0.1 & 1.9 & 0.0 \\
Volvocales & 0.4 & 5.5 & 0.0 \\
Chlorococcales & 8.8 & 36.2 & 0.5 \\
Desmidiales & 0.0 & 0.3 & 0.0 \\
Xantophyceae & 0.1 & 1.1 & 0.0 \\
Chrysophyceae & 40.6 & 93.1 & 2.9 \\
Bacillariophyceae & 0.2 & 3.7 & 0.0 \\
Primnesiophhyta & 0.0 & 0.2 & 0.0 \\
Cryptophyta & 16.9 & 85.7 & 0.0 \\
Dinophyta & 31.8 & 90.3 & 1.0 \\
HETER. FLAG. & & & \\
Chrysophyceae & 78.5 & 100.0 & 6.4 \\
Coanoflagellata & 4.7 & 35.7 & 0.0 \\
Bodonids & 3.6 & 45.0 & 0.0 \\
Criptomonads & 0.2 & 7.6 & 0.0 \\
Non-identified sps & 12.9 & 92.5 & 0.0 \\
CILIATES & & & \\
Gymnostomatida & 22.2 & 100.0 & 0.0 \\
Prostomatida & 30.4 & 100.0 & 0.0 \\
Oligotrichida & 43.1 & 98.2 & 0.0 \\
Others & 1.4 & 47.4 & 0.0 \\
\hline
\end{tabular}

Tab. 4. Range and average of microbial groups biomass ( $\mu \mathrm{g}$ $\mathrm{C}^{-1}$ ) for both ice-free periods studied. Quotient between autotrophic versus heterotrophic biomass. And percentage of the microbial groups biomass versus total microbial biomass for phytoplankton (PHY), and versus heterotrophic biomass for bacteria (BAC), heterotrophic flagellates (HNF) and ciliates (CIL). $\mathrm{N}=$ number of samples with data available.

\begin{tabular}{lccc}
\hline & Range & Average & $\mathrm{N}$ \\
\hline Bacteria & $1.8-9.2$ & 3.9 & 38 \\
Autotrophic picoplankton & $0-0.17$ & 0.01 & 109 \\
Phytoplankton & $1.3-236$ & 39.1 & 104 \\
Heterotrophic flagellates & $0.04-27.8$ & 4.2 & 110 \\
Ciliates & $0-14.6$ & 1.9 & 112 \\
& & & \\
Autotrophic / Heterotrophic & $0.4-18.6$ & 4.3 & 35 \\
\% PHY - total & $29-95$ & 73 & 35 \\
\% BAC - heterotrophic & $11-93$ & 47 & 35 \\
\% HNF - heterotrophic & $2-77$ & 32 & 35 \\
\% CIL - heterotrophic & $0-52$ & 18 & 35 \\
\hline
\end{tabular}



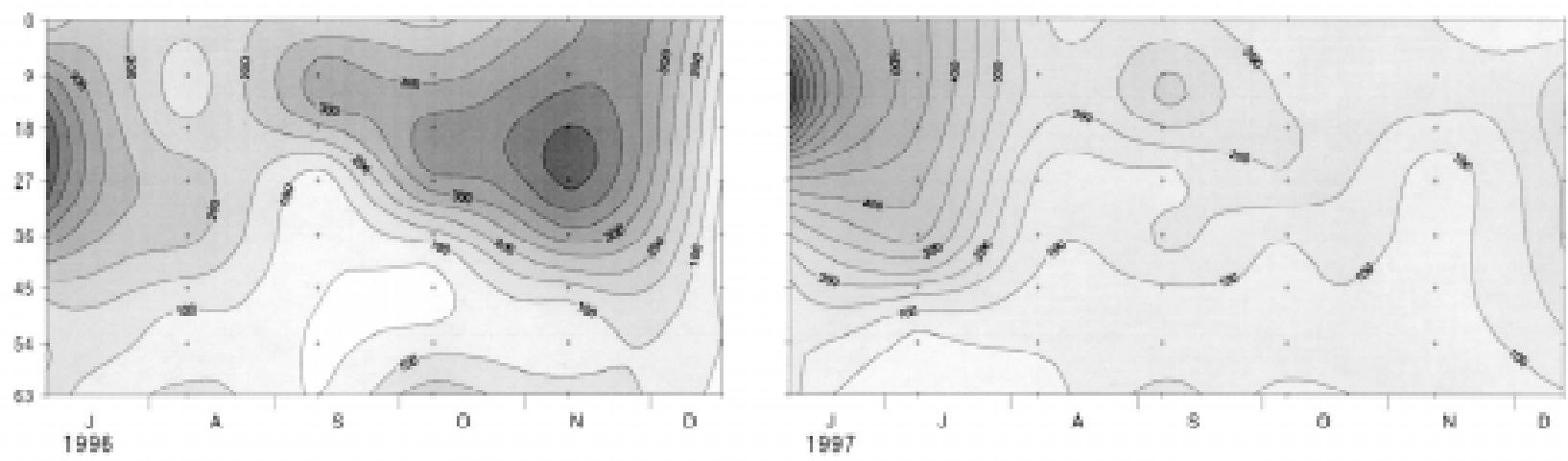

Fig. 3. Isopleths of phytoplankton biovolume $\left(\mathrm{mm}^{3} \mathrm{~m}^{-3}\right)$ for the ice-free period of 1996 and 1997 in Lake Redó. Small crosses indicate sampling points.
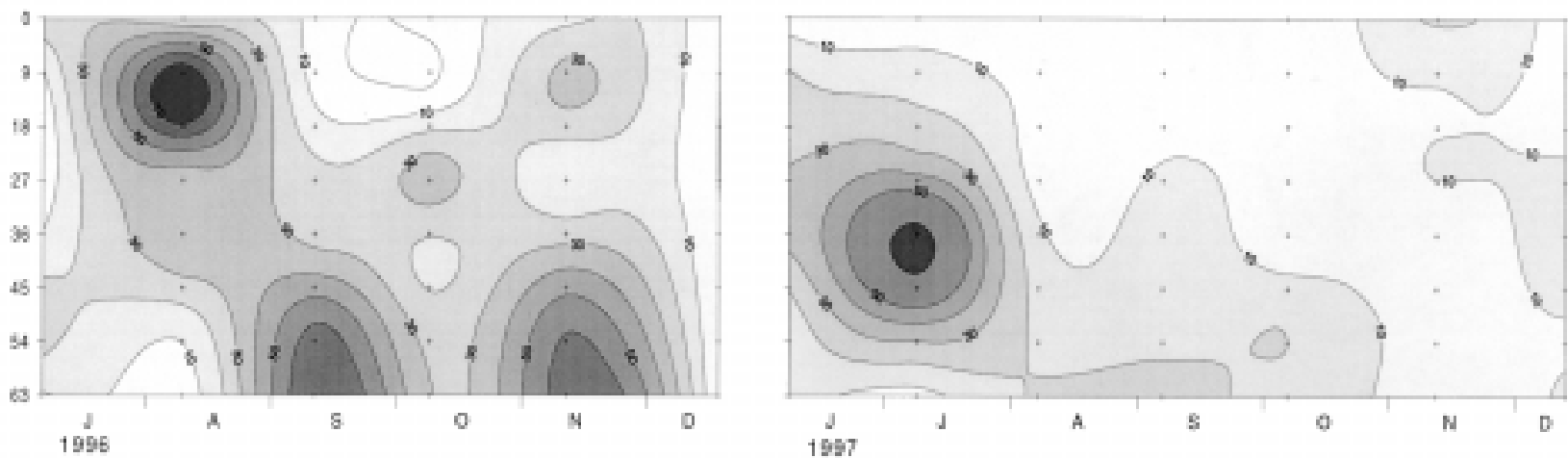

Fig. 4. Isopleths of heterotrophic nanoflagellates biovolume $\left(\mathrm{mm}^{3} \mathrm{~m}^{-3}\right)$ for the ice-free period of 1996 and 1997 in Lake Redó. Small crosses indicate sampling points.
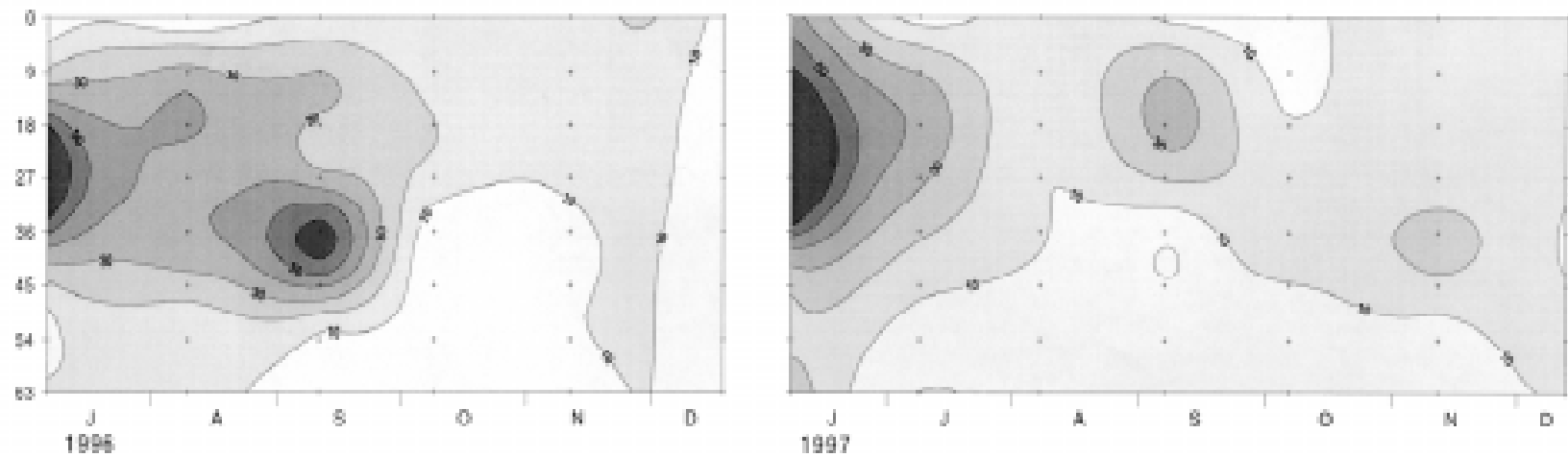

Fig. 5. Isopleths of ciliates biovolume $\left(\mathrm{mm}^{3} \mathrm{~m}^{-3}\right)$ for the ice-free period of 1996 and 1997 in Lake Redó. Small crosses indicate sampling points.

\section{DISCUSSION}

The number of species inhabiting planktonic systems is usually considerable. Although most appear only sporadically, they constitute a pool of biodiversity which allows the ecosystem to respond to changes in environmental conditions (Margalef 1974; Harris 1986). In Lake Redó, we found that $60 \%$ of the species ap- peared in less than $30 \%$ of the samples (Tab. 2). The number of species is not a particularly useful parameter for comparative purposes since it is highly dependent on the counting effort and taxonomical accuracy (Kalff \& Knoechel 1978). Nevertheless, the number of species encountered in Lake Redó is greater (at least in the case of phytoplankton and ciliates) than that recorded in high mountain lakes in the Alps (Felip, unpublished data). 
The morphology of Lake Redó, in particular its depth, might explain this greater diversity in planktonic microorganisms, since the water column provides a larger range of microhabitats.

Tab. 5. Total autotrophic (AUT) and total heterotrophic (HET) plankton biomass during the ice-free period of 1996, values integrated for all water column. And ratio between both plankton components (Aut/Het).

\begin{tabular}{lcccc}
\hline & \multicolumn{2}{c}{ BIOMASS $\left(\mathrm{mg} \mathrm{C} \mathrm{m}^{-2}\right)$} & & RATIO \\
\cline { 2 - 3 } \cline { 5 - 5 } & AUT & HET & & Aut/Het \\
\hline July & 2074 & 552 & & 3.76 \\
August & 949 & 1435 & & 0.66 \\
September & 1174 & 1003 & & 1.17 \\
October & 1463 & 446 & & 3.28 \\
November & 2073 & 782 & & 2.65 \\
December & 455 & 509 & & 0.90 \\
\hline
\end{tabular}

Microbial biomass was dominated by the autotrophic component (phytoplankton); broadly speaking, the microbial plankton biomass was in the following ratios: 10:2:2:1 PHY:HNF:BAC:CIL. A study conducted over a whole year showed an increase in the heterotrophic fraction during winter, but phytoplankton still dominated the total microbial biomass (Felip 1997). These microbial plankton ratios were similar to those observed in a oligo-mesotrophic lake by Amblard et al. (1993), but the lack of comparable data means we can not speculate as to the universality of these results. One part of the autotrophic component in Lake Redó is, in fact, composed of mixotrophic algae, such as Gymnodinium, Chromulina, Ochromonas, Dinobryon cylindricum, and Cryptomonas ovata, which can behave partially or entirely as heterotrophs (Popovský \& Pfiester 1990; Kristiansen \& Andersen 1986; Bird \& Kalff 1986; Sanders $\&$ Porter 1988). Given their frequency in the samples and their abundance (Tab. 2), whether these species should be considered autotrophic or heterotrophic would make a significant difference to the ratio between both compartments. On the other hand, some ciliate species found in Lake Redó might also be mixotrophs (Dolan 1992), though they constituded only a small fraction of the biomass and as such would not change the pattern drawn significantly. A study of biomass distribution in freshwater plankton communities, with data from 57 lakes (Del Giorgio \& Gasol 1995), showed an increase in the ratio between autotrophic and heterotrophic biomasses from unproductive to extremely productive lakes, and suggested a tendency toward higher heterotrophic proportions in oligotrophic systems. What we observed in Lake Redó, when zooplankton data were available (summer 1996), was that the ratio between autotrophic and heterotrophic biomass varied from month to month (Tab. 5). Periods with a higher propor-
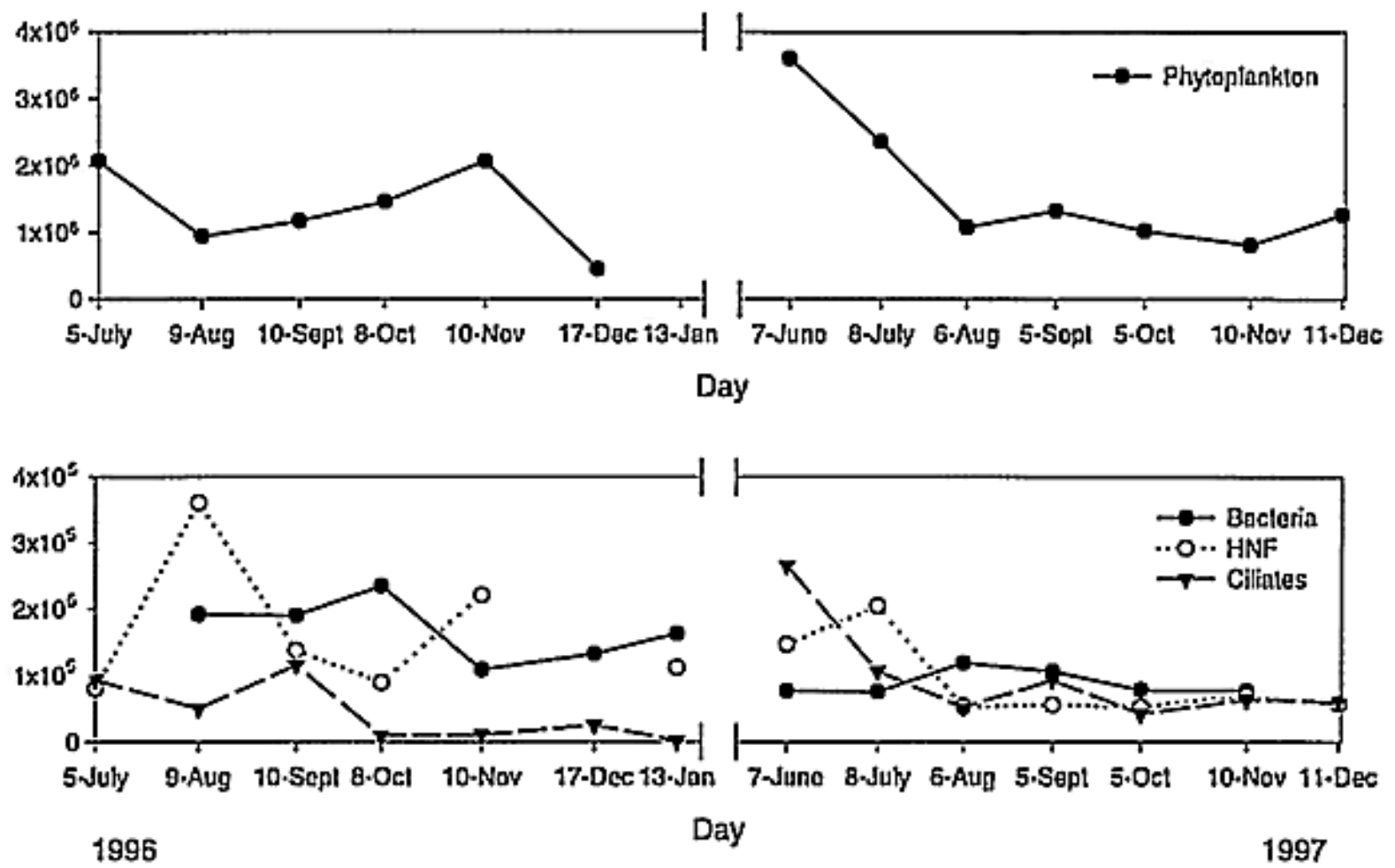

Fig. 6. Temporal distribution of microbial plankton biomass $\left(\mu \mathrm{g} \mathrm{C} \mathrm{m}{ }^{-2}\right.$ ), for each group and throughout the ice-free period of 1996 and 1997. Note the change in biomass scale (y axis) between the two graphs. 
tion of autotrophic biomass were followed by periods in which plankton was dominated by the heterotrophic component (Tab. 5). This was due either to an increase of zooplankton biomass (as was the case in August because of an increase in Dyaptomus abundance) or to a large decrease in phytoplankton biomass (December).

Bacteria was the most significant contributor to heterotrophic biomass (Tab. 4), nevertheless heterotrophic flagellates and ciliates occasionally showed higher biomasses than bacteria (Fig. 6), and no differences were observed between the average biomasses of heterotrophic flagellates and bacteria (Tab. 4). Bacterial abundance and biomass did not change significantly with depth (data not shown) or time (Fig. 6), which could indicate a stationary state of bacterial growth and fate rates, though it might simply reflect the precision of the detection method. Were there to be a stationary state of bacterial growth, then the bacteria abundance observed could be related to a threshold value below which grazing by bacterivores or other mortality factors, such us viruses, become inefficient (Güde 1989, Murray \& Jackson 1992).

The main characteristics of planktonic algae in Lake Redó can be summarized as follows: low number of autotrophic picoplankton, diatoms, xanthophyceae and prymnesiophyta; high number of small cells, and a dominance of flagellated forms (Chrysophyceae, Dinophyta) over non-flagellated cells (mainly Chlorococcales and the chrysophycea Stichogloea doerdeleinii) which increased during the autumn mixing period. The increase in non-flagellated cells during the autumn mixing period has been observed on a previous occasion (Felip 1997). This pattern seems to be quite general, although changes in the species involved and in the proportion of non-flagellated cells occurred. For instance, during autumn 1984 non-flagellated cells represented up to $90 \%$ of phytoplankton biovolume and the desmidiacea Cosmarium sp., rare in 1996-97 (Tab. 2), reached high abundances.

The average and range of phytoplankton biomass found (Tab. 4) are in line with those reported for ultraoligotrophic and oligotrophic lakes (Wetzel 1983). Phytoplankton maxima were related to improved growth conditions due to nutrient input during the column mixing periods, a pattern widely described for oligotrophic dimictic lakes. Ciliates and heterotrophic flagellates seem to follow this algae increase, and their maximum was located at the same time (ciliates in June 1997) or later (heterotrophic flagellates in August 1996). However, no clear relationships could be established for the sample periodicity applied here (Fig. 6). There was a significant interannual variation in the microbial plankton community, in terms of species composition and dominance (Tab. 2), and in biomass values and temporal patterns (Figs 3, 4, 5 and 6). In 1996, we did not sample immediately after the lake cover melted, as we had done in 1997 (June sampling), and samples from July in both years were quite similar. In contrast, the pattern for autumn 1996 was different from that observed in 1997. In 1997 an increase in phytoplankton biomass was not recorded (according to chlorophyll content measurements, T. Buchaca, pers. com), and bacteria, heterotrophic flagellates and ciliates biomass were depleted. The consistent appearance of a decline, as indicated from sampling at several dates, suggests that this was not a random event but the result of a collapse in the microbial community due to some general limitation.

\section{ACKNOWLEDGMENTS}

We thank T. Buchaca, LL. Camarero, J. Piera, S. Pla and M. Ventura for field work support. This study was undertaken with the support of the project MOLAR, Measuring and modeling the dynamic response of remote mountain lake ecosystems to environmental change, No. ENV4-CT95-0007 of the Environmental and Climate Program of the European Commission.

\section{REFERENCES}

Amblard, C., T. Sime-Ngando, S. Rachiq \& G. Bourdier. 1993. Importance of ciliated protozoa in relation to the bacterial and phytoplanktonic biomass in an oligo-mesotrophic lake, during the spring diatom bloom. Aquat. Sci., 55:1-9.

Azam, F., T. Fenchel, J.G. Field, J.S. Gray, L.A. Meyer \& F. Thingstad. 1983. The ecological role of water column microbes in the sea. Mar. Ecol. Prog. Ser., 10: 257-263.

Bird, D.F. \& J. Kalff. 1986. Bacterial grazing by planktonic algae. Science, 231: 493-495.

Borsheim K.Y. \& G. Bratbak. 1987. Cell volume to carbon conversion factors for a bacterivorous Monas sp. enriched from seawater. Mar. Ecol. Prog. Ser., 36: 171-175.

Capblanq, J. 1972. Phytoplancton et productivitié primaire de quelques lacs d'altitude dans les Pyrénées. Annales de Limnologie, 8: 231-321.

Catalan, J. 1988. Physical properties of the environment relevant to the pelagic ecosystem of a deep high-mountain lake (Estany Redó, Central Pyrenees). Oecol. aquat., 9: 89-123.

Catalan, J. 1989. The winter cover of a high-mountain Mediterranean lake (Estany Redó, Pyrenees). Water Resour. Res., 25: 519-527.

Catalan, J. 1992. Evolution of dissolved and particulate matter during the ice-covered period in a deep, high-mountain lake. Can. J. Fish. aquat. Sci., 49: 945-955.

Del Giorgio, P. \& J.M. Gasol. 1995. Biomass distribution in freshwater plankton communities. Am. Nat., 146: 135-152.

Dolan, J. 1992. Mixotrophy in ciliates: a review of Chlorella symbiosis and chloroplast retention. Mar. Microb. Food Webs, 6: 115-132.

Felip, M. 1997. Ecologia del microplàncton d'un estany profund d'alta muntanya (Redó, Pirineus). $\mathrm{PhD}$. University of Barcelona.

Felip, M., B. Sattler, R. Psenner \& J. Catalan. 1995. Highly active microbial communities in the ice and snow cover of high mountain lakes. Appl. Environ. Microbiol., 61: 23942401.

Felip, M., Ll. Camarero \& J. Catalan. (1999). Temporal changes of microbial assemblages in the ice and snow cover of a high mountain lake. Limnol. Oceanogr., 44: 973-987. 
Felip, M. \& J. Catalan. (1999). The relationship between phytoplankton biovolume and chlorophyll in a deep oligotrophic lake: decoupling in their spatial and temporal maxima. J. Plankton Res.: (in press).

Güde, H. 1989. The role of grazing on bacteria in plankton succession. In: U. Sommer (Ed.). Plankton Ecology. Springer-Verlag: 337-364.

Halac, S., M. Felip, Ll. Camarero, S. Sommaruga-Wögrath, R. Psenner, J. Catalan \& R. Sommaruga. 1997. An in situ enclosure experiment to test the solar UV-B impact on microplankton in a high altitude mountain lake: 1) lack of effect on phytoplankton species composition and growth. $J$. Plankton Res.,11: 1671-1687.

Harris , G.P. 1986. Phytoplankton ecology: structure, function and fluctuation. Cambridge University Press: $384 \mathrm{pp}$.

Kalf, J. \& R. Knoechel. 1978. Phytoplankton and their dynamics in oligotrophic and eutrophic lakes. Ann. Rev. Ecol. Syst., 9: 475-495.

Kristiansen, J. \& R. A. Andersen (Eds). 1986. Chrysophytes: aspects and problems. Cambridge University Press: 337 pp.

MacIsaac, E.A. \& J.G. Stockner. 1993. Enumeration of photototrophic picoplankton by autofluorescence microscopy. In: P.F. Kemp, B.F. Sherr, E.B. Sherr and J.J. Cole (Eds), Handbook of methods in Aquatic Microbial Ecology. Lewis Publishers: 229-240.

Margalef, R. 1974. Ecología. Omega, Barcelona.

Margalef, R. 1983. Limnología. Omega, Barcelona.

Margalef, R., L. Campas, M.R. Miracle \& J.M. Vilaseca. 1975. Introducción al estudio de los lagos pirenaicos. Naturalia Hispanica, 4: 1-47.

Müller, H. \& W. Geller. 1993. Maximum growth rates of aquatic ciliates protozoa: the dependence on body size and temperature reconsidered. Arch. Hydrobiol., 126: 315-327.

Mullin, M.M., P.R. Sloan \& R.W. Eppley. 1966. Relationship between carbon content, cell volume, and area in phytoplankton. Limnol. Oceanogr., 11: 307-311.

Murray, A. G. \& G. A. Jackson. 1992. Viral dynamics: A model of the effects of size shape motion and abundance of singled-celled planktonic organisms and other particles. Mar. Ecol. Prog. Ser., 89: 103-116.

Norland, S. 1993. The relationship between biomass and volume of bacteria. In: P.F. Kemp, B.F. Sherr, E.B. Sherr \& J.J. Cole (Eds), Handbook of methods in Aquatic Microbial Ecology. Lewis Publishers: 303-307.

Pechlaner, R. 1971. Factors that control the production rate and biomass of phytoplankton in high-mountain lake. Mitt. Internat. Verein. Limnol., 19: 125-145.

Pechlaner, R., G. Bretscho, P. Gollmann, H. Pfeifer, M. Tilzer \& H.P. Weissenbach. 1970. The production process in two high-mountain lakes (Vorderer and Hinteres Finstertaler See, Küthai, Austria). In: Z. Kajak \& Hillbricht (Eds), Productivity problems in freshwaters. Unesco IBP Symp. Kazimier, Poland: 237-267.

Popovský, J. \& A. Pfiester. 1990. Süßwasserflora von Mitteleuropa. Band 6. Dinophyceae. Gustav Fisher Verlag.
Porter, K.G. \& Y.S. Feig. 1980. The use of DAPI for identifying and counting aquatic microflora. Limnol. Oceanogr., 25: 943-948.

Porter, K.J., H. Paerl, R. Hodson, M. Pace, J. Priscu, B. Riemann, D. Scavia \& J. Stockner. 1988. Microbial interactions in lake food webs. In: S.R. Carpenter (Ed.), Complex interactions in lake communities. Springer-Verlag: 209227.

Putt, M. \& D.K. Stoecker. 1989. An experimentally determined carbon:volume ratio for marine "oligotrichous" ciliates from estuarine and coastal waters. Limnol. Oceanogr., 34: 1097-1103.

Sanders R. W. \& K. G. Porter. 1988. Phagotrophic phytoflagellates. In: K. C. Marshall (Ed.), Advances in microbial ecology 10. Plenum: 167-192.

Sherr, E.B. \& B.F. Sherr. 1993. Preservation and storage of samples for enumeration of heterotrophic protists. In: P.F. Kemp, B.F. Sherr, E.B. Sherr \& J.J. Cole (Eds), Handbook of methods in Aquatic Microbial Ecology. Lewis Publishers: $207-212$.

Sommaruga, R. \& F. Garcia-Pichel. 1999. UV-absorving mycosporine-like compounds in planktonic and benthic organisms from a high-mountain lake. Arch. Hydrobiol., 144: 255-269.

Sommaruga, R., B. Sattler, A. Oberleiter, A. Wille, S. Wögrath-Sommaruga, R. Psenner, R. Grones, M. Felip, L1. Camarero, S. Pina \& J. Catalan. (1999). An in situ enclosure experiment to test the solar UVB impact on plankton in a high altitude mountain lake: II) effects on the microbial food web. J. Plankton Res., 21: 859-876.

Sournia , A. (Ed.) 1978. Phytoplankton manual. Unesco.

Stockner, J.G. \& K.G. Porter. 1988. Microbial food webs in freshwater planktonic ecosystems. In: S.R. Carpenter (Ed.), Complex interactions in lake communities. Springer-Verlag: 69-83.

Straškrabová, V., C. Callieri, P. Carrillo, L. Cruz-Pizarro, J. Fott, P. Hartman, M. Macek, J.M. Medina-Sánchez, J. Nedoma \& K. Šimek. 1999. Investigations on pelagic food webs in mountain lakes - aims and methods. In: Straškrabová, V., C. Callieri \& J Fott (Eds), Pelagic food web in mountain lakes. MOuntain LAkes Research Program. J. Limnol., 58(2): 77-87.

Tilzer, M. 1973. Diurnal periodicity in the phytoplankton assemblage of a high mountain lake. Limnol. Oceanogr., 18 : 15-30.

Weisse, T. 1991. The annual cycle of heterotrophic freshwater nanoflagellates: role of bottom-up versus top-down control. J. Plankton. Res., 13: 167-185.

Weisse, T. 1993. Dynamics of autotrophic picoplankton in marine and freshwater ecosystems. In: J.G. Jones (Ed.), Advances in microbial ecology, 13. Plenum Press: 327370.

Wetzel, R.G. 1983. Limnology. $2^{\text {nd }}$ edition. Sangres Collegue: $767 \mathrm{pp}$.

Whatne, B.M., \& H.E. Hansen (Eds). 1997. MOLAR Project Manual.- NIVA report 0-96061: 176 pp. 